\title{
Pachychorioidealis kórképek
}

\author{
Gergely Róbert dr. - Ecsedy Mónika dr. \\ Kovács Illés dr. - Papp András dr. - Resch Miklós dr. - Récsán Zsuzsa dr. \\ Szabó Antal dr. - Nagy Zoltán Zsolt dr.
}

Semmelweis Egyetem, Általános Orvostudományi Kar, Szemészeti Klinika, Budapest

\begin{abstract}
Célunk, hogy közleményünkben összefoglaljuk a pachychorioidealis kórképekkel kapcsolatos ismereteket egy-egy saját esettel illusztrálva. Az irodalmi adatok és a saját klinikai tapasztalatok alapján összegeztük a pachychorioidealis kórképekkel kapcsolatos ismereteinket, az alcsoportok kezelési lehetőségeiről összefoglaló folyamatábrát készítettünk. A pachychorioidealis kórképekbe a következő betegségek tartoznak: centrális serosus chorioretinopathia (CSCR), pachychorioidealis pigmentepitheliopathia (PPE), pachychorioidealis neovasculopathia (PNV), polypoid chorioidealis vasculopathia (PCV), peripapillaris pachychorioidealis syndroma (PPS), focalis chorioideaexcavatio (FCE). A pachychorioidealis kórképek közös jellemzője a chorioidea kvantitatív vagy kvalitatív eltérései, melyekhez gyakran subretinalis folyadékgyülem társul. A betegségcsoportnak jelenleg nincs standard kezelési protokollja; a többféle kezelési mód közül néhány hatékonyabbnak bizonyul, az alcsoportok között azonban lényeges különbségek mutatkoznak. Összegezzük, hogy melyik alcsoportban érdemes eplerenonetablettás kezeléssel, mikropulzuslézerkezeléssel, verteporfinos fotodinámiás kezeléssel (PDT) vagy intravitrealis anti-VEGF-injekciós kezeléssel kezdeni. Orv Hetil. 2020; 162(20): 770-781.
\end{abstract}

Kulcsszavak: pachychorioidealis kórképek, eplerenone, mikropulzuslézer, anti-VEGF, PDT

\section{Pachychoroid diseases}

The aim of this study is to present our knowledge about pachychoroid diseases using case reports, literature review and our own clinical experiences. A summary flow chart of treatment options for the subgroups was prepared, too. Pachychoroid diseases include the following: central serous chorioretinopathy (CSCR), pachychoroid pigment epitheliopathy (PPE), pachychoroid neovasculopathy (PNV), polypoidal choroidal vasculopathy (PCV), peripapillary pachychoroid syndrome (PPS), focal choroidal excavation (FCE). A common feature of pachychoroid diseases is the quantitative or qualitative abnormality of the choroidea, which is often associated with subretinal fluid accumulation. The disease group does not currently have a standard treatment protocol; some of the multiple treatments prove to be more effective, however, there are significant differences between the subgroups. We summarize which subgroup benefits from eplerenone tablet therapy, micropulse laser therapy, verteporfin photodynamic therapy or intravitreal anti-VEGF injection therapy.

Keywords: pachychoroid disease, eplerenone, micropulse laser, anti-VEGF, PDT

Gergely R, Ecsedy M, Kovács I, Papp A, Resch M, Récsán Zs, Szabó A, Nagy ZZs. [Pachychoroid diseases]. Orv Hetil. 2020; 162(20): 770-781.

(Beérkezett: 2020. szeptember 20.; elfogadva: 2020. november 5.)

\section{Rövidítések}

$\mathrm{AQP}=$ (aquaporin) akvaporin; BVN = (branching vascular network) elágazó érhálózat; $\mathrm{CNV}=$ chorioidea-neovascularisatio; $\mathrm{CSCR}=$ centrális serosus chorioretinopathia; DLS = (double-layer sign) kettősréteg-jel; ELM = (external limiting membrane) külső határmembrán; FCE = focalis chorioideaexcavatio; ICG $=$ (indocyanine green $)$ indocianinzöld; $\mathrm{MR}=\mathrm{mi}-$ neralokortikoid-receptor; OCT $=$ (optical coherence tomography) optikaikoherencia-tomográfia; $\mathrm{OS}=$ (outer segment) külső szegmens; PCV = polypoid chorioidealis vasculopathia; PDT $=$ (photodynamic therapy) fotodinámiás kezelés; PED = (pigment epithelial detachment) pigmentepithel-leválás; PIGF $=$ (placental growth factor) placentalis növekedési faktor; PNV $=$ pachychorioidealis neovasculopathia PPE $=$ pachychorioidealis pigmentepitheliopathia; PPS = peripapillaris pachychorioidealis syndroma; RPE = retina-pigmentepithelium; VEGF = (vascular endothelial growth factor) éreredetű endothelialis növekedési faktor 
A pachychorioidealis kórképek megnevezést 2018-ban írták le először, és a következő, korábban már leírt kórképeket foglalja magában: centrális serosus chorioretinopathia (CSCR), pachychorioidealis pigmentepitheliopathia (PPE), pachychorioidealis neovasculopathia (PNV), polypoid chorioidealis vasculopathia $(\mathrm{PCV})$, peripapillaris pachychorioidealis syndroma (PPS), focalis chorioideaexcavatio (FCE) [1-3]. A kórképek ezen csoportosítása fooképp az érhártya elváltozásai miatt történt, melynek eltéréseire, változásaira való odafigyelés kiemelten fontos [4]. A pachychorioidealis kórkép nem azonos a vastag chorioideával (amely fiziológiásan is előfordulhat), a diagnózis felállításakor a chorioidea minóségi elváltozásai is jelen kell, hogy legyenek.

\section{Patomechanizmus és klinikai kép}

\section{Centrális serosus chorioretinopathia}

A CSCR tipikusan a fiatal felnőttek betegségeként került leírásra, mely döntően A-típusú személyiséggel rendelkező fiatal férfiakat érint, később azonban kiderült, hogy az idősebb korosztály és a nők is érintettek lehetnek $[5,6]$. Az exogén kortikoszteroidok a szemészeti alkalmazás kivételével bármilyen formában kiválthatják a betegséget az arra hajlamos személyekben, de ezenkívül ismert, hogy adrenergreceptor-agonisták (orrspray-ben lévő oximetazolin, a testépítők által használt efedra, az amfetaminok) és foszfodiészteráz-5-inhibitorok (szildenafil, tadalafil) használata után is megjelenhet a kórkép [7].
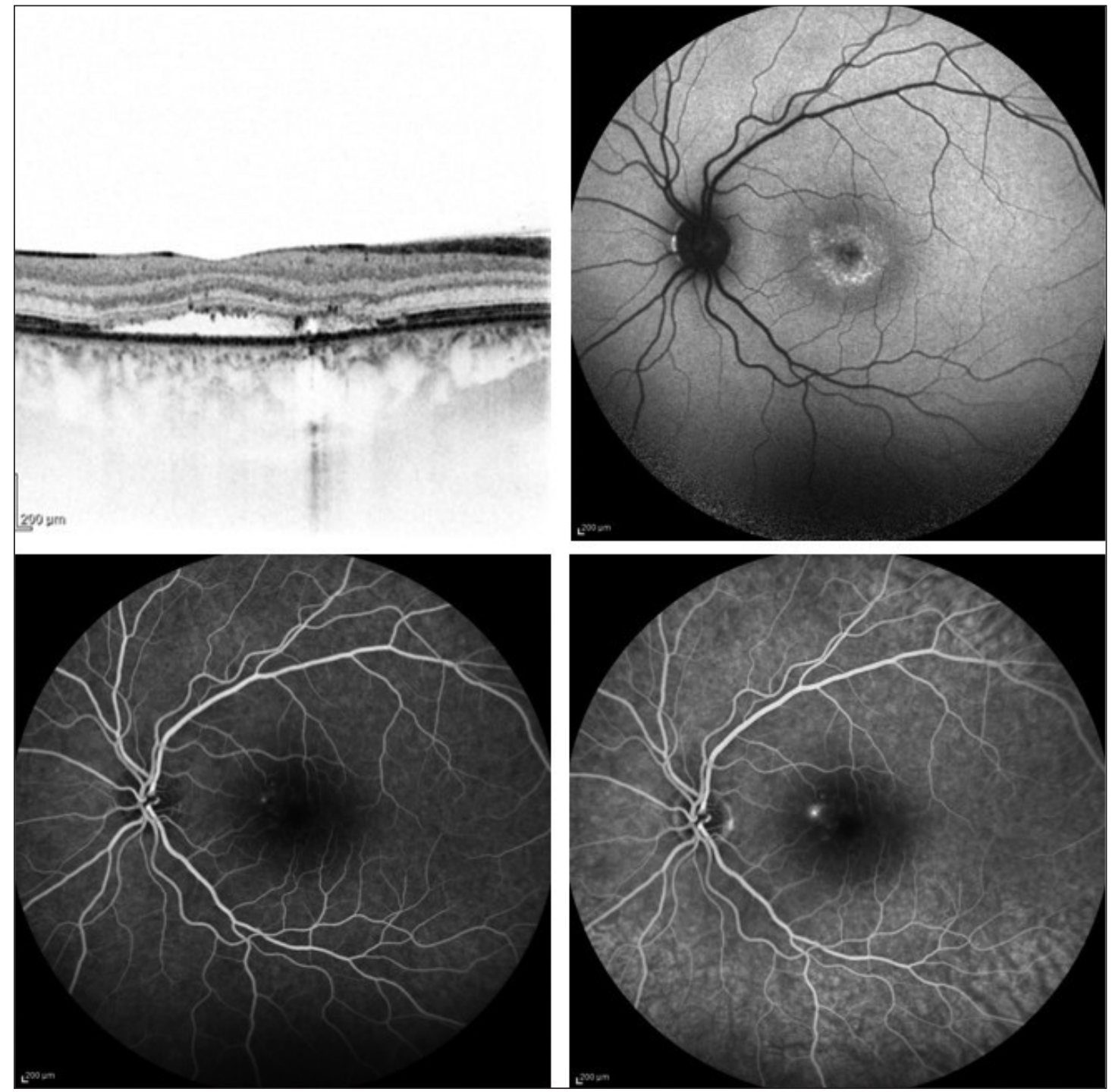

1. ábra

Centrális serosus chorioretinopathia (CSCR). OCT-felvételen a subretinalis folyadék mellett a krónikus formára jellemző, külső retinarétegekben jelen lévő hiperreflektív pontok láthatók; jelen esetben az ELM- és az OS-réteg folytonossági hiánya is jelen van. A choriocapillaris réteg elvékonyodott, a Haller-réteg megvastagodott, az itt lévő erek kifejezetten tágultak (bal felső kép). Fundus-autofluoreszcenciával jól azonosítható a pigmenthám érintettsége, mely pettyezett hiper-autofluoreszcenciaként látható (jobb felső kép). Fluoreszcens angiográfia során a fovea nasalis felső szélén kis, felhőszerű szivárgást láthatunk (alsó képek)

ELM = külső határmembrán; OCT = optikaikoherencia-tomográfia; OS = külső szegmens 
Ezenkívül a terhesség 3. trimeszterében és Cushingszindrómában is előfordul, ami szintén az emelkedett kortizolszinttel hozza összefüggésbe a betegséget $[7,8]$. A kockázati tényezők közé sorolják a cardiovascularis betegségeket és a magas vérnyomást, CSCR-betegekben pedig nagyobb valószínúséggel fordul elő alvási apnoe és gastrooesophagealis reflux, valamint Helicobacter pylori fertőzés $[7,9]$. A betegség fó klinikai jele a hátsó póluson egy vagy több gócban jelen lévő subretinalis folyadékgyülem, mely az esetek nagy százalékában az első 2-3 hónapban spontán felszívódást mutat [7]. Krónikus esetnek a legalább 4 hónapja folyamatosan fennálló betegséget tartjuk: ilyenkor pigmentzavar is láthatóvá válik a szemfenéken, valamint optikaikoherencia-tomográfiás (OCT-) felvételeken hiperreflektív pontok jelennek meg a külső magvas és a fotoreceptor-rétegben. A fennállási idő növekedésével a külső retinarétegek károsodása (ELM: external limiting membrane = külső határmembrán, fotoreceptor-OS: outer segment = külső szegmens) is megfigyelhető $[7,10]$ (1. ábra). Újabb vizsgálatok kimutatták, hogy a retina elváltozásai mellett a chorioidea megvastagodása is hozzátartozik a betegséghez [11, 12]. Ezt követően nem sokkal a chorioidea kvalitatív elváltozásai is leírásra kerültek (choriocapillaris elvékonyo- dás és a Sattler-, valamint a Haller-réteg ereinek tágulata); jelenleg inkább ez utóbbit tekintik a betegségre jellemzőnek, mintsem kizárólag a számszerú chorioideavastagsági érték növekedését $[2,7]$.

\section{Pachychorioidealis pigmentepitheliopathia}

A „pachychorioidea” megnevezést Warrow és munkacsoportja említi elsőként egy 2013-ban megjelent közleményben [13]. A szerzők PPE-nek nevezték azokat az eseteket, amelyekben a maculatáji pigmentzavarnak megfelelő területen a chorioidea megvastagodása volt látható olyan betegeknél, akiknél korábban nem volt subretinalis folyadékgyülem [13]. A subretinalis folyadékgyülem hiányán kívül a leírt betegség minden tekintetben megfelelt a CSCR-ben látott elváltozásoknak, ezért ezt forme fruste CSCR-nek is gondolták, ami a betegség teljes mértékben ki nem bontakozott formáját jelenti [13]. A szemfenéki jelek azonosak azokkal, amelyeket aktív CSCR-betegek másik, subretinalis folyadék nélküli szemén is láthatunk, ezért egyes szerzők a PPE-t a CSCR kezdeti stádiumának vélik. Ezzel ellentétben Warrow és mtsai esetsorozatukban egyik betegnél sem találtak subretinalis folyadékgyülemet a megfigyelési idő
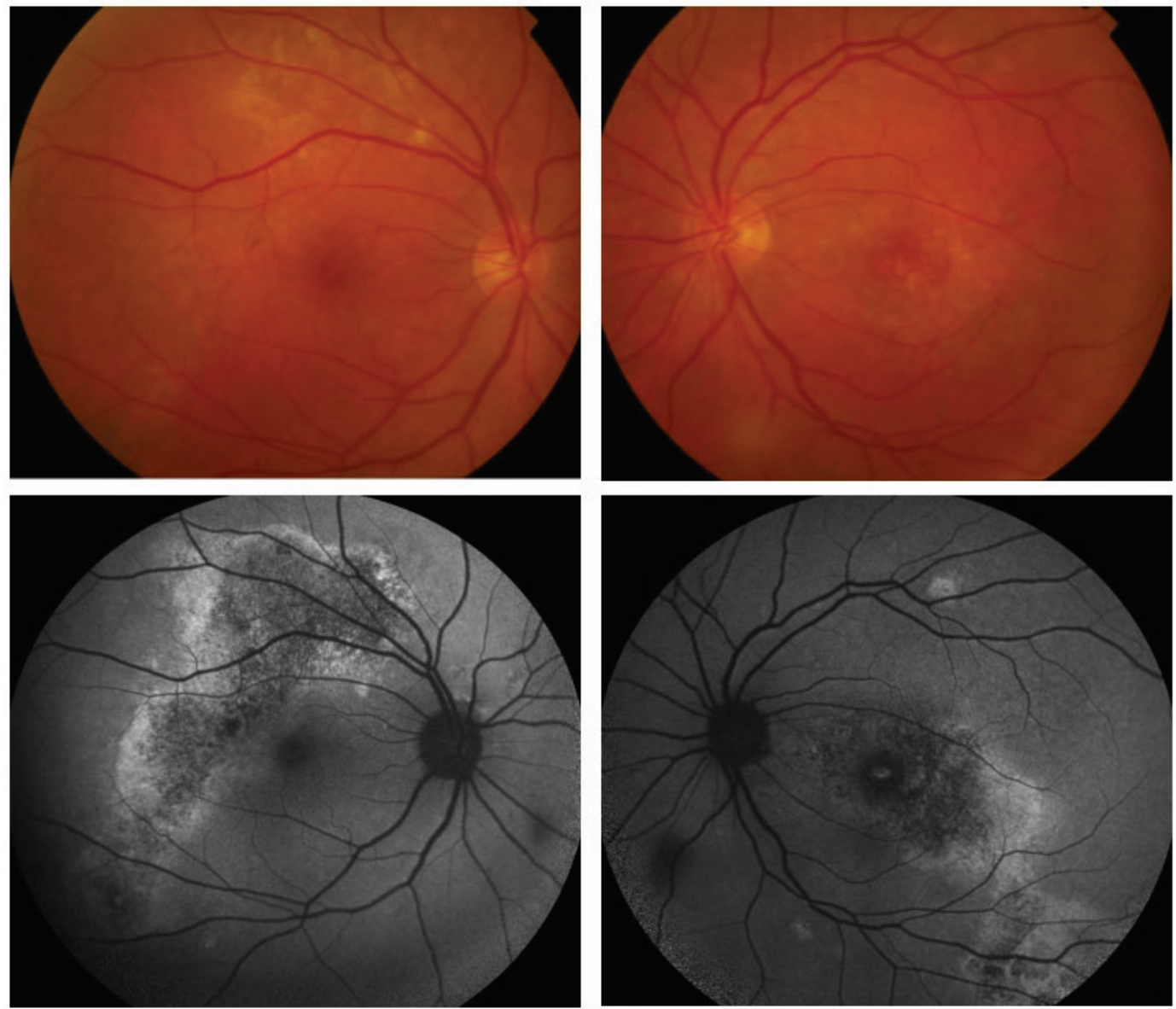

2. ábra

Pachychorioidealis neovasculopathia (PNV). A szemfenéken enyhe pigmentzavar látható mindkét szemen, drusenek nincsenek (felső képek). Ugyanazon beteg fundus-autofluoreszcenciás felvételein a pigmentzavarnak megfelelő területen granuláris hipo- és hiperfluoreszcencia látható (alsó képek) 
alatt, és kiemelik a szemfenéken másképpen megmutatkozó pigmentzavar-eltéréseket is [13]. Krónikus CSCRben a pigmentzavar gravitációs sávok formájában vagy foltos hiperfluoreszcenciaként látható a korábbi subretinalis folyadékgyülemnek megfelelő részeken, míg PPEben inkább finomabb, granuláris jellegű a pigmentzavar, váltakozó hipo- és hiperfluoreszcenciával és a gravitációs sávok hiányával [13]. A betegség első leírásával ellentétben manapság a pachychorioidea megnevezést nemcsak a chorioidea kvantitatív változásával, megvastagodásával teszik egyenlővé, hanem az kvalitatív és funkcionális eltéréseket is magában foglal, így a chorioidea nagyereinek tágulata, a choriocapillaris elvékonyodása, valamint az indocianinzöld (ICG)-angiográfián kimutatható érfali hiperpermeabilitás is idetartozik. A pachychorioidea ezáltal nem azonos és fóképp nem felcserélhető a megvastagodott chorioidea elnevezéssel, azért sem, mert kimutatták, hogy egészséges emberekben is lehet vastagabb a chorioidea [1-3, 14]. Ezenkívül a fiziológiás chorioideamegvastagodás is relatíve széles határokon belül mozog, a legtöbb szerző a $300 \mu \mathrm{m}$ alatti értékeket tekinti a normáltartományon belülinek $[4,14]$.

\section{Pachychorioidealis neovasculopathia}

Pang és mtsai 2013-ban írták le az általuk PNV-nek nevezett kórképet [15]. Közleményükben olyan, subretinalis folyadékgyülemmel és l-es típusú érújdonképződéssel járó eseteket mutattak be, amelyeknél korábban nem volt CSCR, maculadegeneratio vagy egyéb maculatáji degeneratív elváltozás, és a chorioidea körülírt vagy focalis eltérése volt látható [15] (2. ábra). A betegség jellemzője, hogy a pigmentzavarnak megfelelő területen, a subretinalis folyadékgyülem mellett OCT-vel lapos, hullámos pigmentepithel-leválást (PED) látunk, melyet kettősréteg-jelnek nevezünk (DLS: double-layer sign). Az elváltozás alatt mélyebben a chorioidea focalis megvastagodása vagy a chorioidea nagyereinek (Haller) tágulata és az alatta lévő rétegek (Sattler, choriocapillaris) elnyomódása, elvékonyodása látható [15] (3. ábra). A subretinalis folyadékgyülem általában kisebb mértékű és laposabb, mint a CSCR-ben látott folyadékgyülem. A kóros, hiperpermeábilis chorioideaterület a szemfenéki képen csökkent táblázottságként látható [15]. A DLS-t OCT-vel három sávként látjuk, a két hiperreflektív réteg
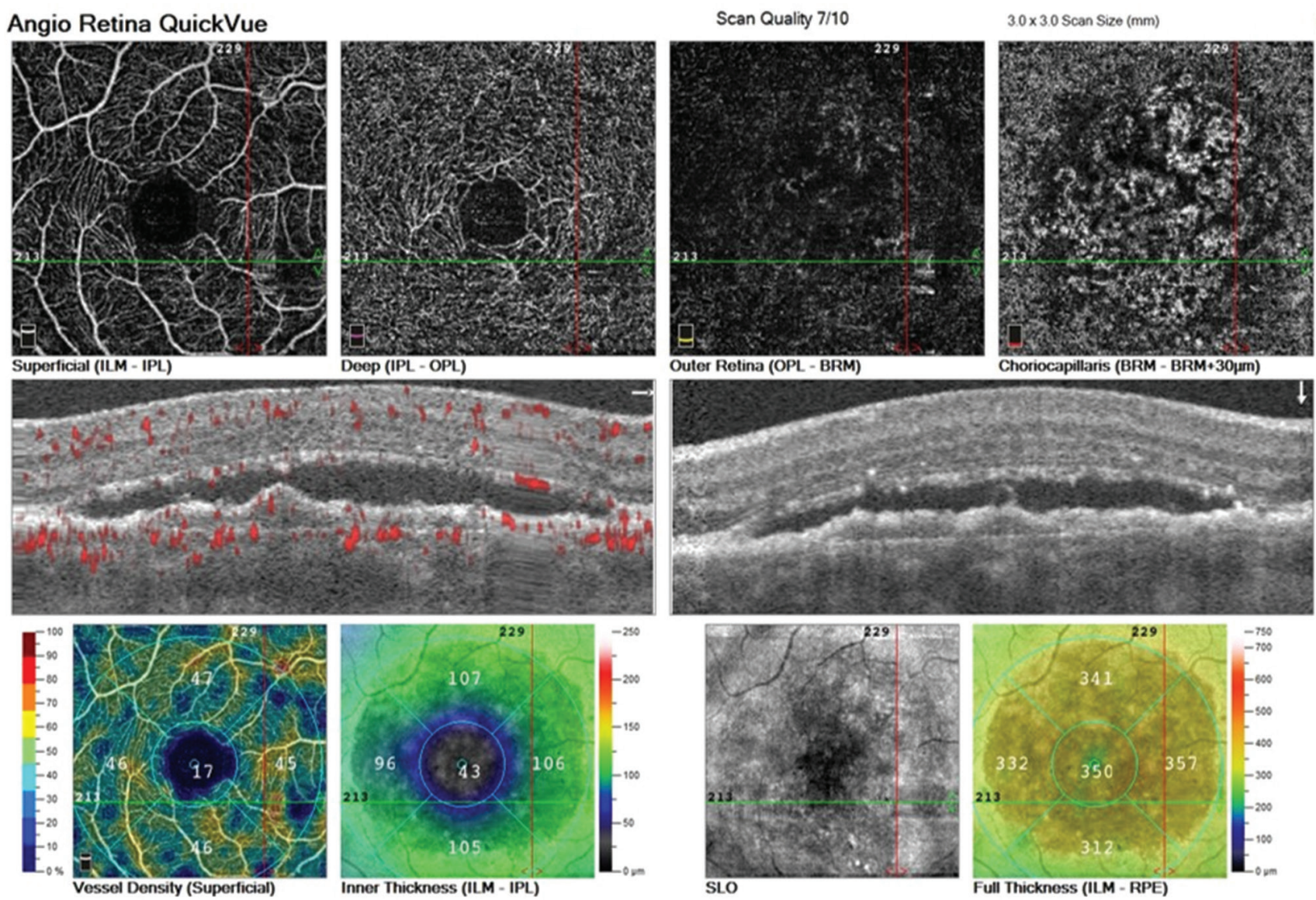

Choriocapillaris (BRM - BRM+30um)
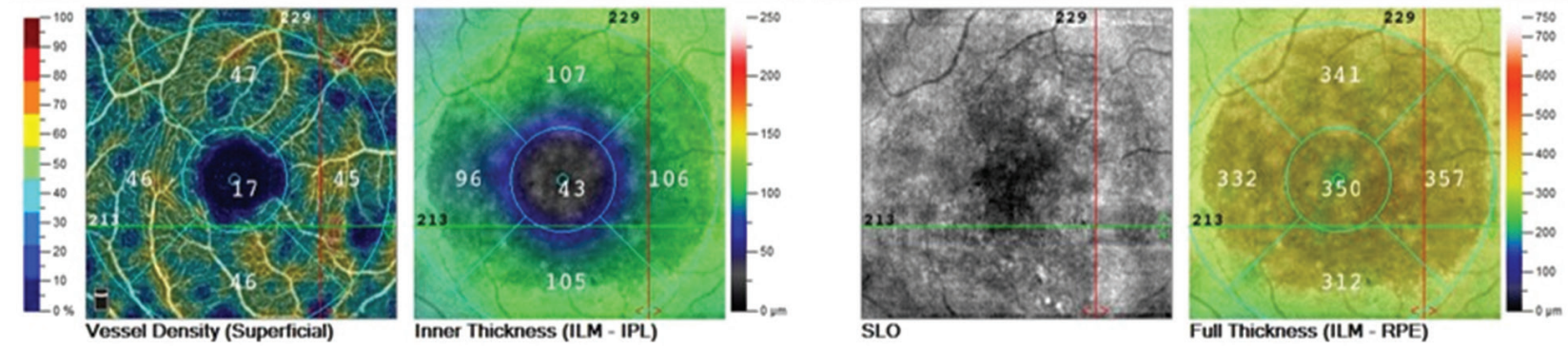

3. ábra $\quad$ Pachychorioidealis neovasculopathia (PNV). OCT-felvételen lapos, hullámos PED látható a subretinalis folyadékgyülemen kívül (középső képek). Az OCT-angiográfiás felvételeken a külső retina- és a choriocapillaris rétegben abnormális érhálózatnak megfelelő eltérés figyelhető meg (felső képek)

OCT = optikaikoherencia-tomográfia; PED = pigmentepithel-leválás 
(a retina-pigmentepithelium és a Bruch-membrán) között levő, enyhén reflektív réteg az érújdonképződésnek megfelelő polypoid elváltozás, mely ICG-angiográfia során korai hiperfluoreszcens foltként és elágazó érhálózatként (BVN: branching vascular network) látható [15]. Az elváltozás idővel egyre vaskosabb BVN-t és nagyobb polypoid képződményeket képez, emiatt egyes szerzők a PNV-t a PCV kezdeti formájának is tartják [15].

\section{Polypoid chorioidealis vasculopathia}

A közel 40 éve először leírt PCV terminológiája az évek során sokat változott, de fó jellemzője a mai napig azonos az akkor leírtakkal: a maculatájon vagy gyakran a papillához közeli részen narancsos-vöröses nodulusokat, „polypusokat” látunk, és az intraretinalis és/vagy a subretinalis folyadékgyülem mellé serosus vagy vérzéses PED és lipidexudatio társulhat a hátsó póluson [16]. A szemfenéki jelek alapján klinikailag elkülöníthetünk inaktív, serosus vagy haemorrhagiás PCV-t. OCT-vel gyakran látható az „ujj-jel” vagy az „M-jel”: ez a PED-ek belső felén, a pigmenthámhoz tapadva a hiperreflektív gyưrúként látható polypusokat jelöli, melyek ICG-angiográfia során egy BVN korai foltos szivárgást mutató kiboltosuló nodulusai [16] (4. ábra). Az ellátó érhálózat és a polypusok mérete nagyon változó, az apró, csak festés során észrevehető és a nagy, tükrözéskor is szembetünő képződmények között széles az elváltozások skálája. $\mathrm{Az}$ intraretinalis folyadék mértéke általában kisebb a ma- culadegeneratióban látottakhoz képest, ahogyan a drusenek jelenléte is jóval ritkább, és ekkor is csak néhány látható, a legtöbbször parafovealisan [16]. A betegséghez a retina-pigmentepithelium (RPE) rupturája, subretinalis fibrosis, pigmenthám-hyperplasia és atrophia társulhat [16]. Újabb post mortem vizsgálatok kimutatták, hogy a PCV-ben látott polypusok valóban vékony falú erek focalis értágulatai, melyeket esetenként pericyták is körülvesznek, az elváltozásnak azonban ez csak egy részét képezi, és nagyrészt fibrovascularis membrán, gyulladásos sejtek és granulációs szövet alkotja az elváltozást [17]. Ezek alapján arra a következtetésre jutottak, hogy a polypusok az 1-es típusú érújdonképződés egyfajta megjelenési formáját képezik, és emiatt javasolt rá inkább a polypoid chorioidealis neovascularisatio (polypoid CNV) megnevezés [17].

Az ok-okozati összefüggések azonban korántsem tisztázottak. A BVN-nek megfelelő területen levő érújdonképződést szövettani metszeteken és OCT-felvételeken is az RPE- és a Bruch-membrán között azonosították, ami tovább bizonyítja azt a hipotézist, miszerint a betegség elsődlegesen nem chorioideopathia, nem a chorioidea saját ereinek patológiás elváltozásából ered közvetlenül, hanem az érhártya érújdonképződésének hosszas fennállása után kialakuló értágulat okozza, és ehhez chorioideaeltérések is társulnak [15, 18]. Ezzel szemben más szerzők szövettani vizsgálatok során azt mutatták ki, hogy a polypusok valójában a belső chorioidea ereinek tágulatai, melyek hialinizálódnak, és jelentős plazmapro-
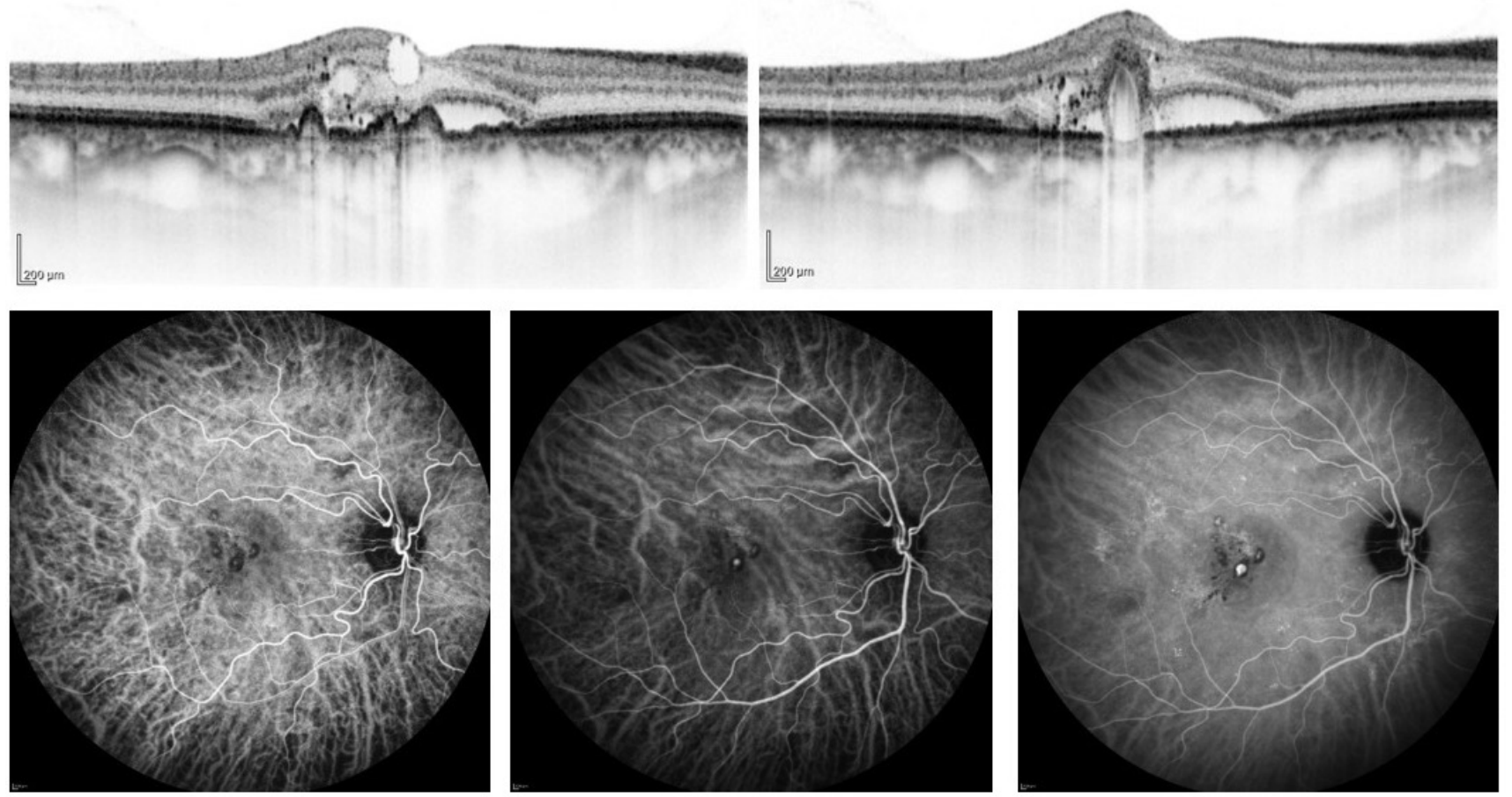

4. ábra

Polypoid chorioidealis vasculopathia (PCV). OCT-felvételeken a pigmenthám lapos, hullámos, M-jelú vagy ujj-jelű elváltozása látható a subretinalis és intraretinalis folyadékgyülemen kívül. A chorioidea nagyereinek focalis subfovealis megvastagodása szembetűnő (felső képek). Indocianinzöld-angiográfia során ugyanezen beteg maculájában 7 kis polypoid képlet rajzolódik ki (alsó képek)

OCT $=$ optikaikoherencia-tomográfia 
tein-eresztést okoznak, de CNV-re jellemző granulációs szövetszaporulat nem látható, és az érendothelsejtek is VEGF-negatívak [19]. Esetenként a polypusok mellett érújdonképződést is azonosítottak, ami arra utalhat, hogy két különálló patológiás folyamattal állunk szemben PCV-ben [19]. A polypusok elhelyezkedését illetően egy részük a Bruch-membrán alatt volt, másrészt viszont az elvékonyodott vagy károsodott Bruch-membránon és akár az RPE-rétegen keresztül is előboltosultak, ami klinikailag 1-es és 2-es típusú CNV-t utánoz [19]. A hialinizált erek körül bazálmembránszerü lerakódások is megfigyelhetők, ami nehezíti a Bruch-membrán és az RPE pontos anatómiai vizsgálatát [19]. Prünte és mtsai esetsorozatukban azt mutatták ki, hogy CSCR-ben az ICG-angiográfiával azonosítható első inzultus a chorioidea focalis ischaemiája, melyet capillaris és vénás pangás követ ezen erek permeabilitásának fokozódásával [20]. A chorioidea hiperpermeabilitása tipikusan az RPE-eltéréseknek megfelelő területen látható, ami arra utal, hogy a retina eltérései másodlagosak $[15,20]$. Multimodális vizsgálatokkal kimutatták, hogy a fentebb leírt klasszikus szemfenéki jelek mellett a chorioidea megbetegedése is fontos jellemzője a kórképnek [15, 17]. A chorioidea focalis vagy diffúz megvastagodása mindig megfigyelhetó (mely csökkent szemfenéki táblázottságként látható), OCT-vel a chorioidea nagyereinek (Haller) tágulata és a choriocapillaris, valamint a Sattler-réteg elvékonyodása látható [17]. A focalis chorioideaeltéréseket általában a BVN-eknek és/vagy a polypusoknak megfelelő területen látjuk [17].

A PPE-, a CSCR-, a PNV- és a PCV-betegség közös jellemzője tehát a chorioidea kóros elváltozása, mely mellett csak pigmentzavar, vagy pigmentzavar és subretinalis folyadékgyülem, vagy pigmentzavar, subretinalis folyadékgyülem és 1-es típusú érújdonképződés, vagy a felsoroltak mindegyike és az érújdonképződés aneurizmális tágulatai láthatók, melyeket polypusoknak nevezünk. Emiatt a fenti kórképeket többen egyazon betegség különböző stádiumainak vélik. Ugyanakkor az is elképzelhető, hogy ezek egy betegség különböző fenotípusai. Több, hosszabb követési idejű esetközlemény arról számol be, hogy a betegeknél úgy alakul ki PNV vagy $\mathrm{PCV}$, hogy korábban semmilyen szemfenéki pigmentzavar vagy subretinalis folyadékgyülem nem volt látható. Másrészt vannak esetek, amikor a beteg egyik szemén PNV vagy PCV látható, a másikon pedig a PPE jelei azonosíthatók.

\section{Peripapillaris pachychorioidealis syndroma}

A PPS-t 2018-ban írták le [21]. A betegség a legjobban a krónikus CSCR-re hasonlít, azzal a különbséggel, hogy intraretinalis cystoid ürök is jelen vannak, valamint a chorioidea megvastagodása nasalis irányba eltolt. Általában idősebb, hypermetrop férfiakat érint a betegség [21]. A patomechanizmust illetően a peripapillaris chorioideában a pangás hatására bekövetkező compart- mentsyndromához hasonló elváltozásokat feltételeznek [21]. Szemfenéki képen a papilla körül pigmentzavart látunk, mely hiper-autofluoreszcens pettyezettséggel jár, és fluoreszcens angiográfia során szivárgás nem azonosítható; a pettyezett hiperfluoreszcenciát a pigmentzavarnak megfelelő ablakeffektus magyarázza [21] (5. ábra). ICG-angiográfiás felvételek korai fázisában a peripapillaris és papillomacularis régióban tágult chorioideaerek láthatók, melyek a középső fázisban a hiperpermeabilitásnak megfelelően szivárgást mutathatnak [21]. OCTfelvételeken a papillától temporalisan intraretinalis cystoid ürök minden esetben jelen vannak, melyekhez kisebb PED-ek és subretinalis folyadékgyülem is társulhat [21] (6. ábra). A chorioidea megvastagodott, és/vagy a chorioidea nagyereinek tágulata szembetúnő a choriocapillaris réteg elvékonyodása mellett [21]. A CSCR-es és az egészséges szemekkel ellentétben ebben a betegségben a
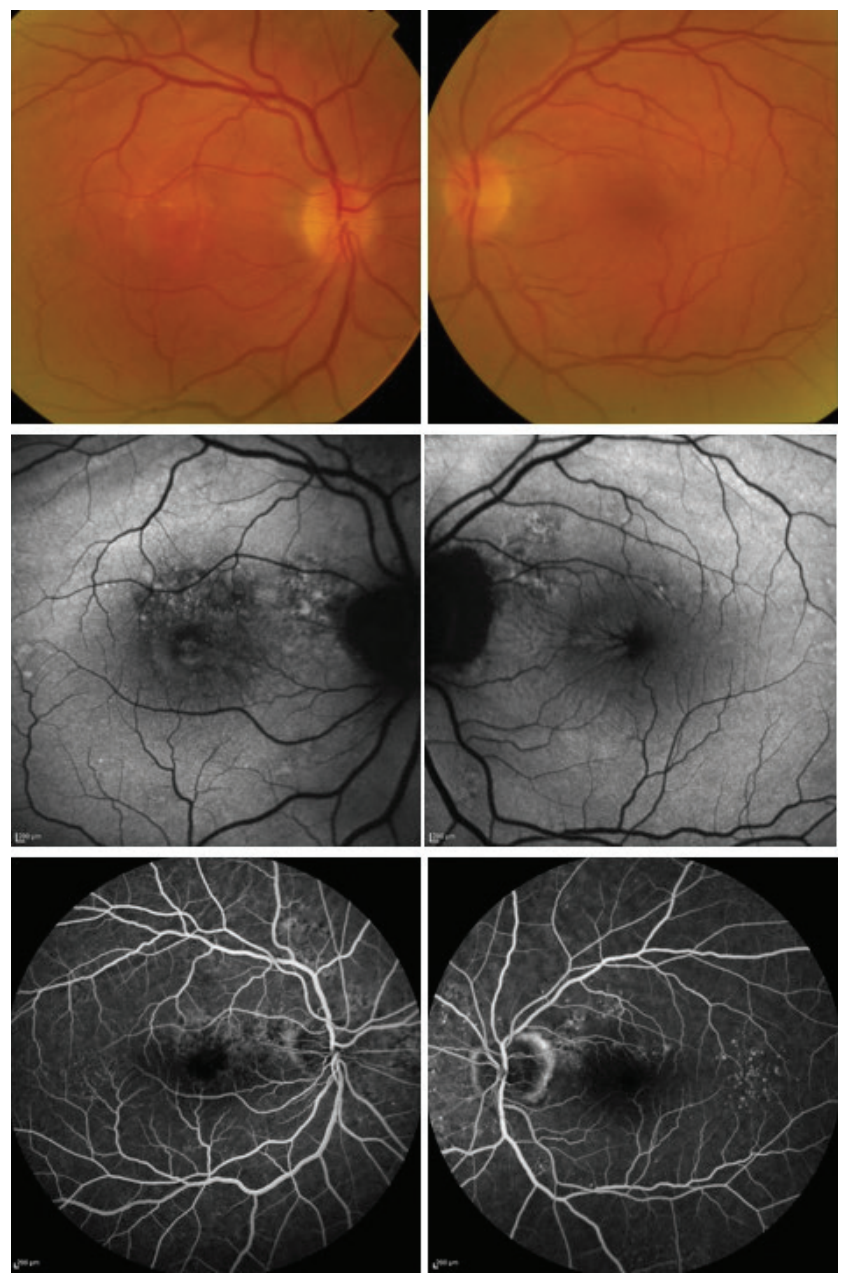

5. ábra

Peripapillaris pachychorioidealis syndroma (PPS). A szemfenéken enyhe pigmentzavart látunk a maculában és a papilla körül (felső képek). Fundus-autofluoreszcencia során szembetúnőbb a pigmentzavarnak megfelelő terület, emellett a középső jobb képen a foveában a subretinalis és intraretinalis folyadékgyülem okozta hiperfluoreszcencia, a középső bal képen a papillomacularis zónában jelen lévő intraretinalis cystoid űrök által okozott hiperfluoreszcencia is látható. A fluoreszcens angiográfiás felvételeken pettyezett hiperfluoreszcencia látható, mely megfelel a pigmentzavar miatti ablakeffektusnak (alsó képek) 

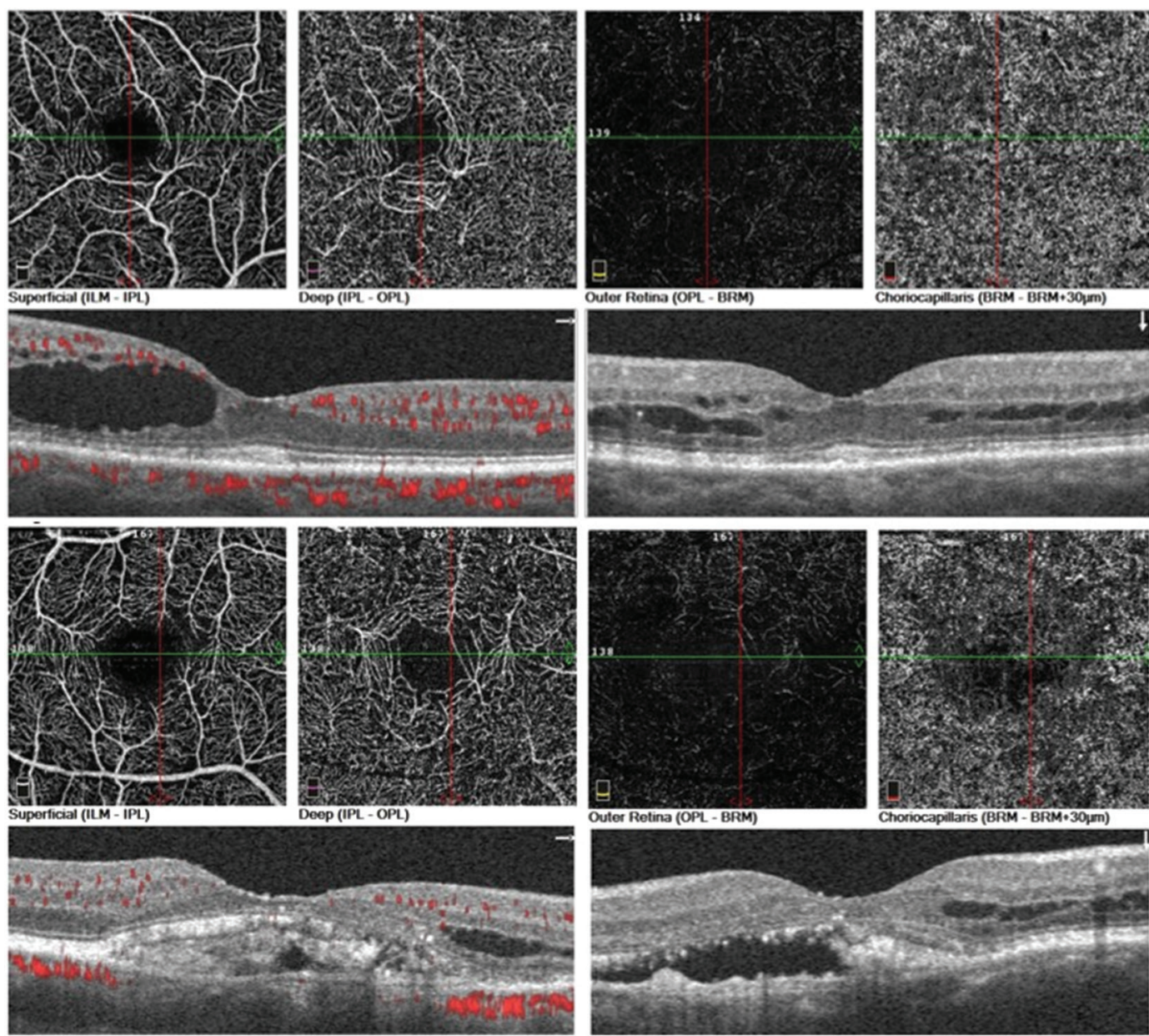

ina (OPL - BRM)

Choriocapillaris (BRM - BRM+30ym)

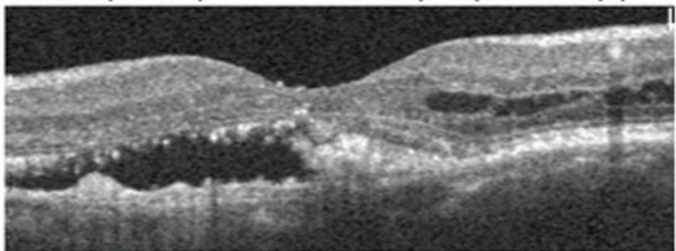

6. ábra

Peripapillaris pachychorioidealis syndroma (PPS). Az 5. ábrán bemutatott beteg OCT- és OCT-angiográfiás felvételei: subretinalis és intraretinalis folyadékgyülem, valamint subretinalis massza látható (két felső kép: jobb szem; két alsó kép: bal szem)

OCT $=$ optikaikoherencia-tomográfia

chorioidea legvastagabb pontja a macula nasalis részén van, de peripapillarisan is vastagabb, mint az előző két esetben. Esetenként a korábbi subretinalis folyadékgyülemnek megfelelően gravitációs sávok is láthatók a papilla körüli területen. Az esetek jelentős részében a fluoreszcens angiográfia során a papilla szélének megfelelö, gyưrű alakú festődés látható a késői felvételeken, és ehhez esetenként enyhe szivárgás is társul, egyéb eredetú patológia kizárása mellett [21] (5. ábra). Az esetek többségében a hátsó póluson chorioidearedók is láthatók, emiatt javasolt a differenciáldiagnózisban figyelembe venni a PPS lehetôségét is [21]. Egyes szerzők a kórképet izolált uvealis effusiós syndromaként írták le, mások azonban úgy vélik, hogy PPS-ben egyértelmúen a chorioidea hiperpermeabilitása ez egyik fó patológiás elváltozás, nem pedig a scleralis permeabilitásnak az uvealis effusiós syndromában leírt csökkenése az albumin tekintetében, mely a suprachorioidealis tér folyadékretenciójához és következményes RPE-dekompenzációhoz, valamint exsudativ retinaleváláshoz vezet $[21,22]$. PPS-ben a beteg látóélessége közel teljes is lehet, és nem minden esetben okoz maculabetegségre jellemző tüne- teket, mivel a laesio a foveát nem feltétlenül érinti [21]. A betegséghez társulhat klasszikus CSCR, PNV és PCV is, ami a betegségek közti átfedésekre is rámutat [21].

\section{Focalis chorioideaexcavatio}

Az FCE elnevezést 2011-ben Margolis és mtsai használták először egy olyan betegségre, amely a legjobban maculatáji ál-microstaphylomaként lenne leírható, ugyanis egy körülírt, csak a chorioideát érintő kimélyedést látunk, a chorioscleralis határ azonban folytonos [23]. A szemfenéki képen enyhe, körülírt pigmentzavart, esetenként kisfokú sárgás depozitumot látunk. Az OCT-képen a chorioidea kisfokú, homorú kiboltosulását vehetjük észre, melyet az RPE-réteg mindig követ - a neurosensoros retina azonban követi vagy sem, ezáltal elkülönítve két alformát: az illeszkedő és a nem illeszkedő (conforming és non-conforming) FCE-t [23] (7. ábra). A nem illeszkedő formában a chorioidea kimélyülését nem követi a neurosensoros retina, a fotoreceptorok kültagjai és az RPE között hiporeflektív területet látunk, mely vélhetően subretinalis folyadékgyülemnek 

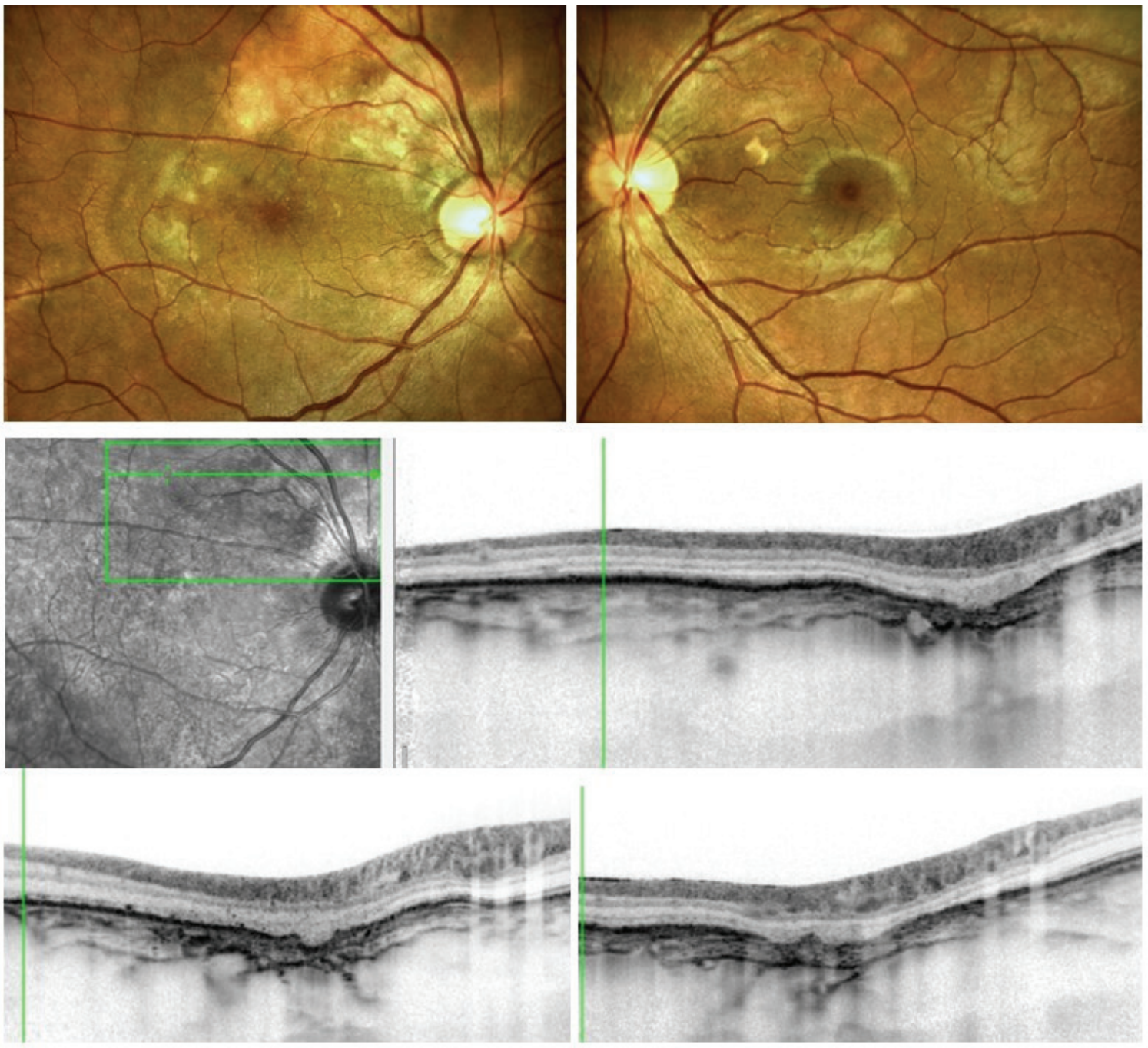

7. ábra
Focalis chorioideaexcavatio (FCE). A jobb szemfenéki képen a macula temporalis és felső szélén az érárkádig terjedően enyhe pigmentzavar látható, a másik szem ép (felső képek). OCT-felvételeken a pigmenthám kifele boltosulása látható, melyet a retina rétegei követnek (illesz- kedő forma); a chorioscleralis határ egyenletes ezen a területen, mutatva, hogy nem colobomáról van szó. A choriocapillaris réteg elvéko- nyodott az excavatio alatt, és a chorioidea nagyerei kifejezetten tágultak mindenhol, a chorioidea összességében megvastagodott (középső és alsó képek)
OCT $=$ optikaikoherencia-tomográfia

felel meg [23]. A betegséget a legtöbbször középfokú myopiás betegeknél írják le; gyakran aszimptomatikus és stacioner vagy nagyon lassú progresszió várható [23]. A betegség congenitalis eredete is felmerül, melynek során egy ideig a neurosensoros réteg rugalmassága tudja követni a chorioidea excavatióját, majd megszakad a rétegek közti kapcsolat, és a folyamat felgyorsul. Esetenként az FCE mellett CSCR-ben is leírták a beteg azonos vagy ellenoldali szemén. A betegség másik jellemzője a chorioidea megvastagodása, még úgyis, hogy döntően myopiás betegekról van szó, akiknél egyébként az átlagnál vékonyabb a chorioidea $[4,14,23]$. Az elváltozás az esetek többségében hipo-autofluoreszcens; fluoreszcens angiográfiás felvételeken az elvékonyodott RPE-réteg miatt az ablakeffektusnak megfelelő hiperfluoreszcencia látható, ICG-angiográfián pedig a choriocapillaris elvékonyodásnak tulajdonítható hipofluoreszcenciát láthatjuk [23].

\section{Kezelés}

A pachychorioidealis kórképekre a mai napig nincs jól bevált kezelési protokoll, azonban az alformákra egyre több kezelési próbálkozás jelenik meg. A régebb óta ismert kórképek (CSCR, PCV) kezelési lehetőségeiről lényegesen több tanulmány látott napvilágot, mint a frissebben leírtakról (FCE, PPE, PNV, PPS).

Az utóbbi években a CSCR elsődlegesen választandó kezelése a mineralokortikoidreceptor-antagonista eplerenonetablettás kúra [24-26]. Alapját az adja, hogy 2010ben Zhao és mtsai kimutatták, hogy a retinában és a chorioideában is találhatók mineralokortikoid-receptorok (MR-ek) [27]. Ezáltal a retina hidráltságát az aldoszteron is befolyásolja azáltal, hogy a Müller-sejtek MR-ein keresztül az akvaporincsatornákat (AQP4) szabályozza $[27,28]$. Azt is kimutatták, hogy a mineralokortikoidok csoportjába tartozó aldoszteron a chorioidea ereire ha- 
tással van, a retina ereire azonban nem $[27,28]$. Az MRekhez glükokortikoidok is képesek kötődni, amennyiben ez magasabb szinten van jelen, és az így kialakuló MRaktiváció a chorioidea erei KCa2.3-csatornáinak 'up-regulatiója' által az érhártya vasodilatatiójához és hiperpermeabilitásához vezet $[27,28]$. Az alaptanulmányt követően több esetsorozat-tanulmány jelent meg azzal kapcsolatban, hogy a per os adott szelektív MR-antagonista eplerenone tablettával történő kezelés után csökken a chorioidea megvastagodása, és felszívódhat a subretinalis folyadékgyülem [25, 26, 29]. A kezelést megelőzően laborvizsgálat (vérkép, szérum-K, vesefunkció) és háziorvosi vagy belgyógyászati javaslat szükséges, tekintettel arra, hogy az eplerenone K-szint-emelkedést és több gyógyszerrel kölcsönhatást okozhat. Az első héten napi $1 \times 25 \mathrm{mg}$, majd ezt követően napi $1 \times 50 \mathrm{mg} \mathrm{az}$ eplerenone adagja, melyet legalább 3 hónapig javasolt szedni, időszakos laborvizsgálat és belgyógyászati felügyelet mellett. A folyadékgyülem felszívódása után a tabletta lassú leépítése (például csökkentése napi 25 mgra 2-4 hétig) egyes esetekben hasznosnak bizonyul, ellenkező esetben a folyadékgyülem recidiválhat. A szemészeti betegségben alkalmazott kis dózis mellett ritkák és enyhék a mellékhatások (hasmenés, alacsony vérnyomás), de számos gyógyszerrel való kölcsönhatása, valamint a más betegségben és nagyobb dózisban alkalmazott használat mellett leírt súlyosabb mellékhatások miatt fontos a beteg időszakos felülvizsgálata és tájékoztatása. A betegek kezelésre adott válaszában különbség látható a folyadékgyülem felszívódásának mértékében és a látóélesség javulásának tekintetében is [30]. Az ép külső retinaréteggel rendelkező betegeknél nagyobb valószínúséggel várható kedvezőbb hatás az eplerenonekezelés után [30]. A gyógyszeres kezelés mellett a szemészet más területén is alkalmazott verteporfinos fotodinámiás (PDT-) kezelés vagy a mikropulzuslézer-kezelés jöhet szóba. Az első kezelések a maculadegeneratio kezeléséből ismert protokollt használták $\left(6 \mathrm{mg} / \mathrm{m}^{2}\right.$ verteporfin, $689 \mathrm{~nm}$-es diódalézerrel $600 \mathrm{~mW} / \mathrm{cm}^{2}$ fényerősséggel 83 másodperc alatt $50 \mathrm{~J} / \mathrm{cm}^{2}$ teljes energia), később azonban az ischaemiás, sorvadásos szövődmények elkerülése végett inkább a felezett dózisú $\left(3 \mathrm{mg} / \mathrm{m}^{2}\right.$ verteporfin) vagy felezett energiájú $\left(25 \mathrm{~J} / \mathrm{cm}^{2}\right)$ kezelések terjedtek el $[31,32]$. Az újabb, mikropulzusmódra is képes lézerek közül az 577 nm-es Navilas mikropulzuslézer (OD-OS GmbH, Teltow, Németország) tünik a leghatékonyabbnak és a legbiztonságosabbnak $[33,34]$. A készülék szemmozgást követő rendszerének, valamint a közvetlen kezelés előtt készített fundusfotón felállítható kezelési tervnek köszönhetően a kezelés kiemelt pontossággal végezhető, fájdalommentesen és nonkontakt módon $[33,34]$. A külső eszközökön készített felvételek (OCT, érfestés) ráilleszthetők a kezelési tervre, ezáltal tovább fokozva a pontosságot és elkerülve a feleslegesen kezelt macularészeket $[33,34]$. A PDT és a mikropulzuslézer hatékonyságáról több összehasonlító tanulmány született, melyek a két kezelést egyformán hatékonynak, esetenként az egyiket vagy a másikat jobbnak vélik [33, $35,36]$. Az ellentmondásra az adhat magyarázatot, hogy mindkét kezelésnek többfajta beállítási lehetősége van, kis esetszámon történtek a vizsgálatok, ráadásul a különböző hullámhosszon múködő mikropulzuslézer-készülékek hatékonysága sem azonos, így nehezített az adatok valódi összehasonlíthatósága. A CSCR intravitrealis antiVEGF- (vascular endothelial growth factor) injekcióval történő kezeléséről korábban néhány esetközlés történt (még a PNV leírása előtt), később azonban kimutatták, hogy CSCR-ben a VEGF-szint azonos az egészséges egyének értékeivel, emiatt bizonyítottnak látszik, hogy CSCR-ben az anti-VEGF-kezelésnek nincs terápiás hatása $[37,38]$.

A PNV kezeléséről egyelőre kevés közlemény található az irodalomban, ezek az anti-VEGF-, valamint a PDTkezelés hatékonyságát írják le külön-külön vagy kombinált terápiában, egybehangzó eredmény azonban a preferált kezelési módról nem született [39, 40]. Terao és mtsai közleményükben arról számolnak be, hogy az intravitrealis anti-VEGF-injekcióval kezelt, maculadegeneratiós és PNV-s betegek száraz és nedves maculaállapotú szemeinek üvegtestében a VEGF-A és a PlGF (placental growth factor) szintje eltérő, a maculadegeneratióval ellentétben PNV-ben alacsony a hormonok szintje, és nincs változás a kezelést követően, ami a két betegség különböző patogenezisére utalhat [41].

PCV-ben két fó kezelési lehetőség van: az intravitrealis anti-VEGF-injekció és a standard verteporfinos PDT-kezelés. Az említett kezelések külön-külön vagy kombinált hatásosságát többen vizsgálták, részben nagy, randomizált tanulmányok keretében [42-45]. A monoterápiaként vagy a PDT-vel kombináltan alkalmazott intravitrealis anti-VEGF-injekciós kezelés hatékonyabbnak látszik a csak PDT-kezeléssel szemben [42-45]. Egyes szerzók arról számolnak be, hogy a PCV altípusától függően változó a kétfajta kezelésre adott terápiás válasz [46]. Míg a PCVl-altípusban (amelyben ICG-angiográfia alapján azonosítható a polypushoz vezetó ér) az anti-VEGF a hatásosabb, addig a PCV2-formában (polypushoz vezető ér nélkül) a PDT bizonyul jobb választásnak [46]. Az említett kezelések előtt az extrafovealis polypusok argonlézer-kezelésével is történtek próbálkozások, azonban a kezelés mellékhatásai (hegesedés, vérzés, másodlagos CNV kialakulása) miatt jelenleg ezt nem használjuk PCV kezelésére. Ezzel ellentétben egyes újabb közlemények az extrafovealis PCV argonlézeres kezelésének (532 nm, 100-200 m, 150-300 ms) hatásosságát írják le, melyhez lényeges folyadékgyülem esetén anti-VEGF-kezelés társítását javasolják [47]. A Navilas lézerrendszerrel tovább növelhető a kezelés biztonságossága, és csökkenthető a felesleges károsodás mértéke, mivel a készülék szemkövető rendszerének köszönhetően a kezelés alatt a polypusok ismételten és pontosan ugyanott kezelhetők, míg ezek elzáródnak, egyúttal mellőzve a nagyobb energia okozta heg kialakulását. 


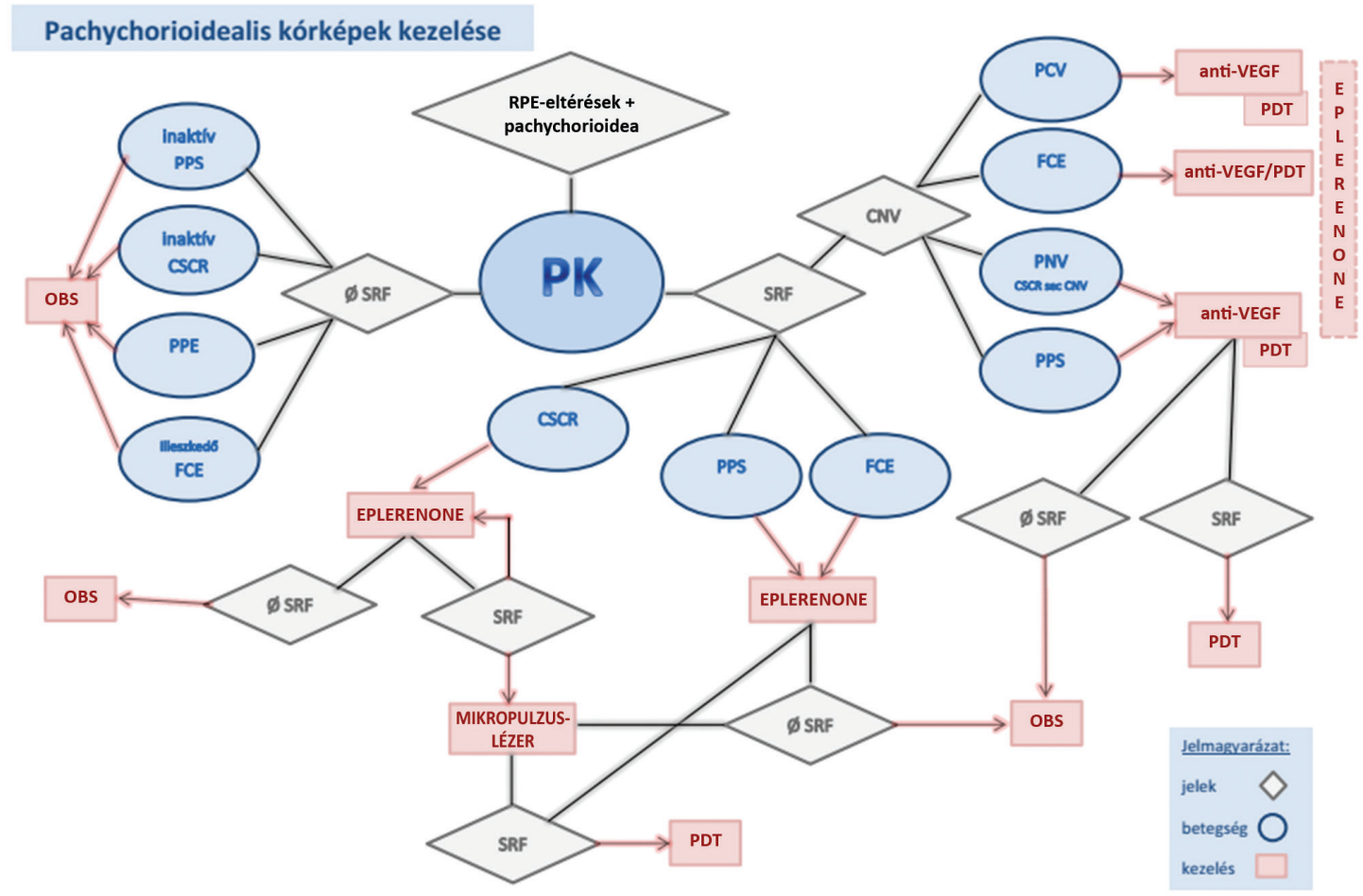

8. ábra

\begin{abstract}
A pachychorioidealis kórképek kezelési sémája
$\mathrm{CNV}=$ chorioidea-neovascularisatio CSCR = centrális serosus chorioretinopathia $; \mathrm{FCE}=$ focalis chorioideaexcavatio; $\mathrm{OBS}=$ obszerváció; $\mathrm{PCV}=$ polypoid chorioidealis vasculopathia; PDT = fotodinámiás kezelés; $\mathrm{PK}=$ pachychorioidealis kórképek; PNV = pachychorioidealis neovasculopathia; $\mathrm{PPE}=$ pachychorioidealis pigmentepitheliopathia; $\mathrm{PPS}=$ peripapillaris pachychorioidealis syndroma; $\mathrm{RPE}=$ retina-pigmentepithelium; $\mathrm{SRF}=\mathrm{subre}-$ tinalis folyadék; VEGF = éreredetú endothelialis növekedési faktor
\end{abstract}

A PPE, az illeszkedő FCE és az inaktív polypust mutató PCV kezeléséról közlemények nem lelhetők fel az irodalomban, folyadékgyülem hiányában a megfigyelést javasolják [2, 3, 13]. Nem illeszkedő FCE esetén az OCT-n látott hiporeflektív ûrt folyadékgyülemnek vélik, emiatt egy-egy esetközlésben a PDT, valamint az intravitrealis anti-VEGF-injekciós kezelés hatásosságáról olvashatunk [48]. Kovács és mtsai esetközlésükben azonban arról számolnak be, hogy egy érújdonképződéshez társult illeszkedő FCE esetében az anti-VEGF-kezelés az FCE növekedését és nem illeszkedő formává alakulását okozta [49]. A PPS hatásos kezeléséről nem található közlemény az irodalomban [50].

A kezelési lehetőségeket sematikusan a 8 ábrán összegezzük.

\section{Következtetés}

A pachychorioidealis kórképek közös jellemzője a chorioidea kvantitatív vagy kvalitatív eltérése, melyhez gyakran subretinalis folyadékgyülem társul, esetenként pedig az érújdonképződésnek valamilyen formája is kialakul. A betegségcsoportnak jelenleg nincs standard kezelési protokollja, a többféle kezelési mód közül néhány hatékonyabbnak bizonyul, az alcsoportok között azonban lényeges különbségek mutatkoznak. Randomizált, multicentrikus tanulmányok hiányában a kezelőorvosnak az egyéni eseteket külön-külön és nagyobb körültekintéssel kell értékelnie, hogy meghozhassa a beteg számára megfelelö döntést.

Anyagi támogatás: A közlemény megírása anyagi támogatásban nem részesült.

Szerzői munkamegosztás: G. R.: Irodalomkutatás, a közlemény írása. E. M., K. I., P. A., R. M., R. Zs., Sz A., N. Z. Zs.: szakmai véleményezés, kritikai revízió. A közlemény végleges változatát valamennyi szerző elolvasta és jóváhagyta.

Érdekeltségek: A szerzőknek nincsenek érdekeltségeik.

\section{Irodalom}

[1] Stepanov A, Studnička J, Středová M, et al. Pachychoroid disease of the macula. Cesk Slov Oftalmol. 2018; 74: 3-8.

[2] Cheung CM, Lee WK, Koizumi H, et al. Pachychoroid disease. Eye $2019 ; 33$ : 14-33.

[3] Freund KB, Fine HF. Pachychoroid disease. Ophthalmic Surg Lasers Imaging Retina 2020; 51: 206-209.

[4] Récsán Zs. Importance of choroidal thickness in eye diseases. [A chorioidea-vastagság jelentősége szemfenéki kórképekben.] Szemészet 2019; 156: 48-58. [Hungarian] 
[5] Kitzmann AS, Pulido JS, Diehl NN, et al. The incidence of central serous chorioretinopathy in Olmsted county, Minnesota, 1980-2002. Ophthalmology 2008; 115: 169-173.

[6] Perkins SL, Kim JE, Pollack JS, et al. Clinical characteristics of central serous chorioretinopathy in women. Ophthalmology 2002; 109: 262-266.

[7] Daruich A, Matet A, Dirani A, et al. Central serous chorioretinopathy: recent findings and new physiopathology hypothesis. Prog Retin Eye Res. 2015; 48: 82-118.

[8] Carvalho-Recchia CA, Yannuzzi LA, Negrão S, et al. Corticosteroids and central serous chorioretinopathy. Ophthalmology 2002; 109: 1834-1837.

[9] Wu CY, Riangwiwat T, Rattanawong P, et al. Association of obstructive sleep apnea with central serous chorioretinopathy and choroidal thickness: a systematic review and meta-analysis. Retina 2018; 38: 1642-1651

[10] Ecsedy M, Gergely R. Central serous chorioretinopathy. In: Récsán Zs, Nagy ZZs. (eds.) Optical coherence tomography in ophthalmology. [Chorioretinopathia centralis serosa OCT leképezése. In: Récsán Zs, Nagy ZZs. (szerk.) Optikai koherencia tomográfia a szemészetben.] Semmelweis Kiadó, Budapest, 2018; pp. 132-137. [Hungarian]

[11] Maruko I, Iida T, Sugano Y, et al. Subfoveal choroidal thickness in fellow eyes of patients with central serous chorioretinopathy. Retina 2011; 31: 1603-1608.

[12] Jirarattanasopa P, Ooto S, Tsujikawa A, et al. Assessment of macular choroidal thickness by optical coherence tomography and angiographic changes in central serous chorioretinopathy. Ophthalmology 2012; 119: 1666-1678.

[13] Warrow DJ, Hoang QV, Freund KB. Pachychoroid pigment epitheliopathy. Retina 2013; 33: 1659-1672.

[14] Sanchez-Cano A, Orduna E, Segura F, et al. Choroidal thickness and volume in healthy young white adults and the relationships between them and axial length, ammetropy and sex. Am J Ophthalmol. 2014; 158: 574-583.el.

[15] Pang CE, Freund KB. Pachychoroid pigment epitheliopathy may masquerade as acute retinal pigment epitheliitis. Invest Ophthalmol Vis Sci. 2014; 55: 5252.

[16] Imamura Y, Engelbert M, Iida T, et al. Polypoidal choroidal vasculopathy: a review. Surv Ophthalmol. 2010; 55: 501-515.

[17] Balaratnasingam C, Lee WK, Koizumi H, et al. Polypoidal choroidal vasculopathy: a distinct disease or manifestation of many? Retina 2016; 36: 1-8

[18] Sato T, Kishi S, Watanabe G, et al. Tomographic features of branching vascular networks in polypoidal choroidal vasculopathy. Retina 2007; 27: 589-594.

[19] Nakashizuka H, Mitsumata M, Okisaka S, et al. Clinicopathologic findings in polypoidal choroidal vasculopathy. Invest Ophthalmol Vis Sci. 2008; 49: 4729-4737.

[20] Prünte C, Flammer J. Choroidal capillary and venous congestion in central serous chorioretinopathy. Am J Ophthalmol. 1996; 121: 26-34.

[21] Phasukkijwatana N, Freund KB, Dolz-Marco R, et al. Peripapillary pachychoroid syndrome. Retina 2018; 38: 1652-1667.

[22] Pautler SE, Browning DJ. Isolated posterior uveal effusion: expanding the spectrum of the uveal effusion syndrome. Clin Ophthalmol. 2015; 9: 43-49.

[23] Margolis R, Mukkamala SK, Jampol LM, et al. The expanded spectrum of focal choroidal excavation. Arch Ophthalmol. 2011; 129: 1320-1325.

[24] Ecsedy M, Gergely R, Kovács I, et al. Central serous chorioretinopathy (CSCR). New diagnostic and therapeutic possibilities. [Centrális serosus chorioretinopathia (CSCR). Új diagnosztikus és terápiás lehetőségek.] Szemészet 2018; 155: 11-17. [Hungarian]

[25] Gergely R, Kovács I, Schneider M, et al. Mineralocorticoid receptor antagonist treatment in bilateral chronic central serous chorioretinopathy: a comparative study of exudative and nonexudative fellow eyes. Retina 2017; 37: 1084-1091.

[26] Bousquet E, Beydoun T, Zhao M, et al. Mineralocorticoid recep tor antagonism in the treatment of chronic central serous chorioretinopathy: a pilot study. Retina 2013; 33: 2096-2102.

[27] Zhao M, Valamanesh F, Celerier I, et al. The neuroretina is a novel mineralocorticoid target: aldosterone up-regulates ion and water channels in Müller glial cells. FASEB J. 2010; 24: 34053415 .

[28] Zhao M, Célérier I, Bousquet E, et al. Mineralocorticoid receptor is involved in rat and human ocular chorioretinopathy. J Clin Invest. 2012; 122: 2672-2679.

[29] Ghadiali Q, Jung JJ, Yu S, et al. Central serous chorioretinopathy treated with mineralocorticoid antagonists: a one-year pilot study. Retina 2016; 36: 611-618.

[30] Gergely R, Kovács I, Récsán Zs, et al. Predictive factors of selective mineralocorticoid receptor antagonist treatment in chronic central serous chorioretinopathy. Sci Rep. 2020; 10: 16621.

[31] Park W, Kim M, Kim RY, et al. Comparing effects of photodynamic therapy in central serous chorioretinopathy: full-dose versus half-dose versus half-dose-half-fluence. Graefes Arch Clin Exp Ophthalmol. 2019; 257: 2155-2161.

[32] Ma J, Meng N, Xu X, et al. System review and meta-analysis on photodynamic therapy in central serous chorioretinopathy. Acta Ophthalmol. 2014; 92: e594-e601.

[33] Ntomoka CG, Rajesh B, Muriithi GM, et al. Comparison of photodynamic therapy and navigated microsecond laser for chronic central serous chorioretinopathy. Eye 2018; 32: 1079-1086.

[34] Gergely R, Ecsedy M, Nagy ZZs. Navilas micropulse laser treatment of chronic central serous chorioretinopathy (CSCR). [Krónikus centrális serosus chorioretinopathia (CSCR) Navilas ${ }^{\circledR}$ mikropulzus lézerkezelése.] A Magyar Szemorvostársaság Retina Szekciójának Kongresszusa, Győr, 2019. [Hungarian]

[35] van Rijssen TJ, van Dijk EH, Scholz P, et al. Focal and diffuse chronic central serous chorioretinopathy treated with half-dose photodynamic therapy or subthreshold micropulse laser: PLACE Trial Report No. 3. Am J Ophthalmol. 2019; 205: 1-10.

[36] Roca JA, Wu L, Fromow-Guerra J, et al. Yellow ( $577 \mathrm{~nm})$ micropulse laser versus half-dose verteporfin photodynamic therapy in eyes with chronic central serous chorioretinopathy: results of the Pan-American Collaborative Retina Study (PACORES) Group. Br J Ophthalmol. 2018; 102: 1696-1700.

[37] Lim JW, Kim MU. The efficacy of intravitreal bevacizumab for idiopathic central serous chorioretinopathy. Graefes Arch Clin Exp Ophthalmol. 2011; 249: 969-974.

[38] Shin MC, Lim JW. Concentration of cytokines in the aqueous humor of patients with central serous chorioretinopathy. Retina 2011; 31: 1937-1943.

[39] Azuma K, Okubo A, Nomura Y, et al. Association between pachychoroid and long-term treatment outcomes of photodynamic therapy with intravitreal ranibizumab for polypoidal choroidal vasculopathy. Sci Rep. 2020; 10: 8337.

[40] Kitajima Y, Maruyama-Inoue M, Ito A, et al. One-year outcome of combination therapy with intravitreal anti-vascular endothelial growth factor and photodynamic therapy in patients with pachychoroid neovasculopathy. Graefes Arch Clin Exp Ophthalmol. 2020; 258: 1279-1285.

[41] Terao N, Koizumi H, Kojima K, et al. Distinct aqueous humour cytokine profiles of patients with pachychoroid neovasculopathy and neovascular age-related macular degeneration. Sci Rep. 2018; 8: 10520.

[42] Koh A, Lee WK, Chen LJ, et al. EVEREST study: efficacy and safety of verteporfin photodynamic therapy in combination with ranibizumab or alone versus ranibizumab monotherapy in patients with symptomatic macular polypoidal choroidal vasculopathy. Retina 2012; 32: 1453-1464.

[43] Koh A, Lai TY, Takahashi K, et al. Efficacy and safety of ranibizumab with or without verteporfin photodynamic therapy for 
polypoidal choroidal vasculopathy: a randomized clinical trial. JAMA Ophthalmol. 2017; 135: 1206-1213.

[44] Miyamoto N, Mandai M, Oishi A, et al. Long-term results of photodynamic therapy or ranibizumab for polypoidal choroidal vasculopathy in LAPTOP study. Br J Ophthalmol. 2019; 103: 844-848.

[45] Lee WK, Iida T, Ogura Y, et al. Efficacy and safety of intravitreal aflibercept for polypoidal choroidal vasculopathy in the PLANET study: a randomized clinical trial. JAMA Ophthalmol. 2018; 136: 786-793. [Erratum: JAMA Ophthalmol. 2018; 136: 840.]

[46] Honda S, Miki A, Yanagisawa S, et al. Comparison of the outcomes of photodynamic therapy between two angiographic subtypes of polypoidal choroidal vasculopathy. Ophthalmologica 2014; 232: 92-96.

[47] Gemmy Cheung CM, Yeo I, Li X, et al. Argon laser with and without anti-vascular endothelial growth factor therapy for extra- foveal polypoidal choroidal vasculopathy. Am J Ophthalmol. 2013; 155: 295-304.el.

[48] Cebeci Z, Bayraktar Ş, Oray M, et al. Focal choroidal excavation. Turk J Ophthalmol. 2016; 46: 296-298

[49] Kovács KD, Gonzalez LA, Weiss SJ, et al. Focal choroidal excavation expansion following treatment of associated choroidal neovascular membrane. Ophthalmic Surg Lasers Imaging Retina 2019; 51: 54-57.

[50] Alonso-Martín B, de-Lucas-Viejo B, Gimeno-Carrero M, et al. Diagnosis by multimodal imaging in peripapillary pachychoroid syndrome: a case report. Arch Soc Esp Oftalmol. 2020; 95: 248253.

(Gergely Róbert dr., Budapest, Üllői u. 26., 1085 e-mail: dr.robertgergely@gmail.com)

\section{PÁLYÁZATI FELHÍVÁS \\ Gyöngyös Városi Önkormányzat pályázatot hirdet \\ Fogorvosi feladatok ellátására}

Gyöngyös városában, vállalkozási formában, határozatlan időre szóló feladatellátási szerződés keretében a gyöngyösi II. számú fogorvosi körzetben, a Nemzeti Egészségbiztosítási Alapkezelő által kötött szerződés szerinti finanszírozással.

Pályázati feltételek, pályázat benyújtásához mellékelendő iratok:

- fogorvosi képesítés,

- részletes szakmai önéletrajz,

- végzettséget igazoló okmányok másolata,

- OONYI másolata,

- 3 hónapnál nem régebbi erkölcsi bizonyítvány,

- MOK tagság igazolása,

- hozzáiárulás a pályázati anyag elbírálásában résztvevők betekintés jogához.

Előnyben részesül a fogszabályozó szakvizsgával rendelkező pályázó, vagy utolsó éves jelölt a fogszabályozó szakképzésben.

A pályázat benyújtásának határideje: a felhívás megjelenéstől számított 30 nap.

A pályázat elbírálásának határideje:

a benyúitási határidőt követő soros Képviselő-testületi ülés.

A pályázat benyújtásának módja:

- postai úton, a pályázatnak a Gyöngyös Városi Önkormányzat, Hiesz György polgármester részére (3200 Gyöngyös, Fö tér 13.) történő megküldésével,

- a kizárólag elektronikus úton történő jelentkezés érvénytelennek minősül.

\section{A feladat ellátásának időpontja:}

a feladat a döntés meghozatalától számított 2 hónap elteltével látható el.

\section{További felvilágosítás kérhető:}

Gyöngyösi Közös Önkormányzati Hivatal Közigazgatási és Intézményirányitási lgazgatóság:

dr. Horváth Gábor igazgatótól a 06-37/510-329 telefonon, illetve Nagyné Szakál Mária egészségügyi referenstöl a 37/510-353 telefonon vagy személyesen előzetes időpont- egyeztetést követően.

A cikk a Creative Commons Attribution 4.0 International License (https://creativecommons.org/licenses/by/4.0/) feltételei szerint publikált Open Access közlemény, melynek szellemében a cikk bármilyen médiumban szabadon felhasználható, megosztható és újraközölhető, feltéve, hogy az eredeti szerző és a közlés helye, illetve a CC License linkje és az esetlegesen végrehajtott módosítások feltüntetésre kerülnek. (SID_1) 